\title{
Endotypes of Chronic Rhinosinusitis; relationships to disease phenotypes, pathogenesis, clinical findings and treatment approaches.
}

\author{
Atsushi Kato ${ }^{1}$, Anju Peters ${ }^{2}$, Whitney Stevens ${ }^{2}$, Robert Schleimer ${ }^{2}$, Bruce Tan², and \\ Robert Kern ${ }^{2}$ \\ ${ }^{1}$ Northwestern University \\ ${ }^{2}$ Northwestern University
}

April 13, 2021

\begin{abstract}
Chronic rhinosinusitis (CRS) is a common clinical syndrome that produces significant morbidity and costs to our health system. The study of CRS has progressed from an era focused on phenotype to include endotype based information. Phenotypic classification has identified clinical heterogeneity in CRS based on endoscopically observed features such as presence of nasal polyps, presence of comorbid or systemic diseases and timing of disease onset. More recently, laboratory-based findings have established CRS endotype based upon specific mechanisms or molecular biomarkers. Understanding the basis of widespread heterogeneity in the manifestations of CRS is advanced by findings that the three main endotypes, Type 1, 2 and 3, orchestrate the expression of three distinct large sets of genes. The development and use of improved methods of endotyping disease in the clinic is ushering in an expansion of the use of biological therapies targeting Type 2 inflammation now and perhaps other inflammatory endotypes in the near future. The purpose of this review is to discuss the phenotypic and endotypic heterogeneity of CRS from the perspective of advancing the understanding of the pathogenesis and improvement of treatment approaches and outcomes.
\end{abstract}

Endotypes of Chronic Rhinosinusitis; relationships to disease phenotypes, pathogenesis, clinical findings and treatment approaches.

Short Title: Relating endotypes, phenotypes and treatments in CRS

Atsushi Kato*, $\mathrm{PhD}^{1}$, Anju T. Peters*, MD, MSCI ${ }^{1,2}$, Whitney W. Stevens, MD, $\mathrm{PhD}^{1,2}$, Robert P. Schleimer***, $\mathrm{PhD}^{1,2}$, Bruce K. Tan**, MD, MS ${ }^{1,2}$, Robert C. Kern**, MD ${ }^{2}$

*,** These authors contributed equally

*** Correspondence

${ }^{1}$ Division of Allergy and Immunology, Department of Medicine and ${ }^{2}$ Department of Otolaryngology - Head and Neck Surgery, Northwestern University Feinberg School of Medicine, Chicago, IL, USA

Conflicts of Interest: AK reports a consultant fee from Astellas Pharma and a gift for his research from Lyra Therapeutics. AP has served on advisory boards for Sanofi-Genzyme/Regeneron, Optinose, AstraZeneca, Novartis, and GSK. WWS served on advisory boards for GlaxoSmithKline, Genentech, and Bristol Myers Squibb and on a speaker's bureau for GlaxoSmithKline. RPS reports consulting fees from Intersect ENT, Merck, GlaxoSmithKline, Sanofi, AstraZeneca/Medimmune, Genentech, Actobio Therapeutics, Lyra Therapeutics, Astellas Pharma, Allakos and Otsuka. RPS also receives royalties from Siglec-8 and 
Siglec-8 ligand related patents licensed by Johns Hopkins to Allakos Inc. BKT served on advisory boards for Sanofi-Genzyme/Regeneron. RCK is a consultant for Lyra Therapeutics.

Keywords: Chronic Rhinosinusitis, Endotype, Inflammation, Nasal polyps, Phenotype

Word Count: 5,067

Address correspondence to Robert Schleimer, $\mathrm{PhD}$

The Roy and Elaine Patterson Professor

Chief, Allergy and Immunology

Northwestern University Feinberg School of Medicine

240 E. Huron St., Room M-318

Chicago, IL 60611 USA

312-503-0076

rpschleimer@northwestern.edu

\begin{abstract}
Chronic rhinosinusitis (CRS) is a common clinical syndrome that produces significant morbidity and costs to our health system. The study of CRS has progressed from an era focused on phenotype to include endotype based information. Phenotypic classification has identified clinical heterogeneity in CRS based on endoscopically observed features such as presence of nasal polyps, presence of comorbid or systemic diseases and timing of disease onset. More recently, laboratory-based findings have established CRS endotype based upon specific mechanisms or molecular biomarkers. Understanding the basis of widespread heterogeneity in the manifestations of CRS is advanced by findings that the three main endotypes, Type 1, 2 and 3, orchestrate the expression of three distinct large sets of genes. The development and use of improved methods of endotyping disease in the clinic is ushering in an expansion of the use of biological therapies targeting Type 2 inflammation now and perhaps other inflammatory endotypes in the near future. The purpose of this review is to discuss the phenotypic and endotypic heterogeneity of CRS from the perspective of advancing the understanding of the pathogenesis and improvement of treatment approaches and outcomes.
\end{abstract}

\title{
Introduction
}

The study of disease has progressed from an era focused on phenotype, where all information was collected by the physician in collaboration with the patient, with or without the use of tools such as the stethoscope, endoscope, X-ray and Ct scanner. We have witnessed the incorporation of ever more sophisticated laboratorybased findings, collected via microscopy and instruments developed for biochemistry, molecular biology and immunochemistry. Information gleaned by these modern techniques can provide information on the underlying cellular and molecular mechanisms that define the endotype. The purpose of this review is to discuss the phenotypic and endotypic heterogeneity of chronic rhinosinusitis from the perspective of advancing the understanding of the pathogenesis and improvement of treatment approaches and outcomes.

\section{Definition of phenotype and endotype}

To understand clinically observed variability in presentation and outcomes, many chronic diseases have been classified by genotype, phenotype and/or endotype. Genotypic classification subdivides disease based upon genetic polymorphisms and has been of limited utility in CRS ${ }^{1}$, aside from identifying related monogenic conditions like cystic fibrosis ${ }^{2}$ or ciliary dysmotility ${ }^{3}$. Phenotypic classifications utilize clinically observable characteristics and have helped advance understanding of natural history and treatment outcomes. In CRS, phenotypic classification has utilized endoscopically observed features, presence of comorbid or systemic illness and timing of disease onset. Classification of CRS by the presence (CRSwNP) or absence (CRSsNP) of nasal polyps has been the most widely applied phenotyping of CRS. CRSwNP is viewed as a diffuse 
inflammatory process, while CRSsNP is linked, at least in part, to sinus outflow obstruction with secondary inflammation and infection, suggesting presence of a mechanical process ${ }^{4}$. Subclassification by the presence or absence of common comorbidities such as asthma ${ }^{5}$ or allergies ${ }^{6,7}$ has been used. Other phenotypic subclassification has embraced recognized presentations such as Aspirin Triad (AERD, NERD), Allergic Fungal Rhinosinusitis (AFRS), Eosinophilic Granulomatosis with Polyangiitis (EGPA) ${ }^{8}$, Granulomatosis with Polyangiitis (GPA), sinonasal sarcoidosis and CRS with immunodeficiency ${ }^{9}$, although these phenotypes are relatively rare and variably defined.

There has been a growing appreciation that establishment of endotype, which initially involved classification by histologic features such as presence of neutrophilia, eosinophilia, fibrosis, glandular hypertrophy and epithelial dysmorphosis, can provide insight into treatment response or pathobiology. Classification based on the presence of fungi or bacteria, has stimulated debate but not led to emergence of widely used clinical protocols ${ }^{10-14}$. Recent efforts seek to define CRS endotypes based upon specific molecular biomarkers or mechanisms. It is gratifying that endotypes have strong associations with phenotypes and histologic findings. Endotypic disease classification is challenging because considerable tissue is required, pathologist interpretations are variable, endotype assays are not readily accessible and results may be influenced by treatment or unstable ${ }^{15}$. Nonetheless, there is an inexorable shift of interest towards the molecular pathways that underlie endotypes that drive inflammation, remodeling and clinical phenotype ${ }^{16}$. In conjunction with new, specific and powerful interventions targeting molecular pathways, study of endotype holds great promise.

\section{Early studies of CRS heterogeneity and indicators of underlying endotypes}

Studies based on histology quantitated the numbers of eosinophils, mast cells and neutrophils ${ }^{17-22}$. In the West, CRSwNP patients had higher numbers of eosinophils and mast cells while CRSsNP expressed relatively higher levels of neutrophils. Heterogeneity of histology made it clear that there were multiple overlapping processes ${ }^{23,24}$. Specifically, many CRSwNP cases were associated with both eosinophilic and neutrophilic infiltrates, while CF polyps demonstrated a predominance of neutrophils ${ }^{25}$. Furthermore, a subset of CRSsNP cases exhibited elevated eosinophil counts ${ }^{26}$. Changes in remodeling including polypoid edema, glandular hypertrophy and fibrosis have been used to subdivide CRS ${ }^{27-29}$. The combination of tissue remodeling changes together with effector cell infiltrates has recently been proposed in a structured histopathologic classification system of CRS ${ }^{30,31}$. Histological phenotyping to distinguish endotypes is only as good as the specificity of inflammatory cell counts or tissue structural changes evaluated. For example, while current evidence indicates that polyposis reflects formation of a fibrin matrix, this feature can result from at least 3 distinct inflammatory pathways ${ }^{32-34}$. Although tissue eosinophilia and remodeling are probably of value, histopathologic features have not been defined in guidelines and remain experimental.

Early molecular studies indicated that IL-5 and IgE are important biomarkers in eosinophilic CRS while IL-8 is found in neutrophilic CRS ${ }^{35-39}$. Recognition of a $\mathrm{T}$ cell cytokine expression pattern was first made by Bachert and colleagues ${ }^{40}$. Interestingly, Asian CRSsNP expressed high levels of type 1 cytokines ${ }^{41}$ similar to Caucasians, but Asian CRSwNP frequently expressed type 3 and type 1 cytokines, as in contrast to the type 2 skewing in Caucasian polyps (see below for discussions of the three types) ${ }^{42}$. A landmark first attempt to define the CRS endotypes was an international study that utilized a cluster analysis of the presence of preselected biomarkers to distinguish 10 endotypes ${ }^{43}$. The strength of the study was the differential association of these endotypes with the phenotypic presence of asthma or nasal polyposis. The 10 endotypes were further subdivided into 3 groups based on high IL-5, low IL-5 or absence of IL-5 ${ }^{44}$. Although the study did not associate endotype with outcome data, it was an important starting point, and this publication accelerated the search for biomarkers that could, at least in theory, define endotypes that would respond uniquely to endotype-specific therapeutics. $25 \%$

\section{Toward developing a current view of CRS molecular endotypes}

\section{Underlying immunological mechanisms}

Pathology of CRSwNP has been well studied and tissue remodeling, epithelial dysfunction, activation of innate and adaptive inflammatory responses and fibrin deposition seem to be common features in 
CRSwNP ${ }^{45,46}$. CRSwNP is frequently divided into two key endotypes, eosinophilic CRSwNP (ECRSwNP) and non-eosinophilic CRSwNP (NECRSwNP) based on the presence and absence of large numbers of eosinophils in nasal polyp (NP) tissue. Analysis of gene expression in CRS tissues ultimately shifted focus to molecules produced by T lymphocytes of types 1, 2 and 3 (also known as 17) that produce primary cytokines that drive the inflammatory patterns observed in tissues (referred to here as T1, T2 and T3 and Tun, signifying "untypeable").Figure 1 shows microarray data from Chicago using samples from CRS patients illustrating the stark contrast between, and the strong similarity among, patients in the distinct endotypes, and Figure 2 shows a summary/overview of the driving cytokine, source cells and effector cells in the tissues. ECRSwNP is characterized by presence of type 2 (T2) cytokines (IL-4, IL-5 and IL-13) and accumulation of type 2 immune cells including mast cells, basophils, CD4 T helper 2 (Th2) cells, group 2 innate lymphoid cells (ILC2), B cells, M2 macrophages and dendritic cells in addition to eosinophils. For this reason, ECRSwNP is also called T2 CRSwNP ${ }^{45-55}$. NECRSwNP can also be subdivided based on presence of inflammatory cytokines, including the type 1 (T1) endotype based on IFN- $\gamma$ signaling and type 3 (T3) endotype based on IL-17A signaling; infiltrated cell types include neutrophils, lymphocytes and plasma cells 52,56-59. NECRSwNP is highly heterogeneous and the frequency of each endotype varies geographically ${ }^{56-58}$. Transcriptomic approaches help to identify immunological mechanisms in NP ${ }^{60-63}$. Of note, two groups presented distinct gene expression profiles in NP between ECRSwNP and NECRSwNP in Asia and results also showed several similarities ${ }^{56,63}$. Both studies showed that eosinophil- and T2-associated genes including CLC , CCL23 ,CCL26 , SIGLEC8, PRSS33 and ALOX15 were upregulated in ECRSwNP, confirming that ECRSwNP is associated with the T2 endotype ${ }^{56,63}$. In contrast, NECRSwNP showed up-regulation of IFN- $\gamma$-induced genes (CXCL9 , CXCL10 and CXCL11), IL-17A-induced genes (serum amyloid A, CXCL6 and CHI3L1) and neutrophil chemokines (IL-8, CXCL1 and CXCL6), suggesting that NECRSwNP in Asia may display mainly a mixed T1 and T3 endotype with neutrophilia ${ }^{56,63}$. Indeed, Wang and colleagues reported that the T1 and T3 mixed (IFN- $\gamma^{+}, \mathrm{IL}-17 \mathrm{~A}^{+}$) endotype is the most common endotype in NECRSwNP in Beijing ${ }^{56}$. Although ECRSwNP and NECRSwNP showed distinct immunological mechanisms, both result in NP formation, suggesting that some phenotypic features, such as formation of polyps, are not reliable indicators of the transcriptomic pattern or molecular endotype. A summary of gene expression in the primary endotypes and mixed endotypes is found in Figure $\mathbf{3}$.

Transcriptome analysis may have value in identifying genes that are associated with NP formation by extracting shared dysregulated genes in NPs from both ECRSwNP and NECRSwNP. Epithelial-to-mesenchymal transition (EMT) associated genes including HIF1A are elevated in both ECRSwNP and NECRSwNP, suggesting that EMT may be a key event in NP formation ${ }^{46,56,64}$. Although transcriptome analysis identifies similarities between ECRSwNP and NECRSwNP, the upstream pathway for the affected molecules may be different in each endotype. For example, reduced fibrinolysis associated with down-regulation of tissue plasminogen activator (tPA) is a common feature of NPs in T2wNP (ECRSwNP) and T1wNP (NECRSwNP) $32,34,46$.

In contrast to CRSwNP, studies in CRSsNP have been complicated by the use of variable sinonasal biopsy sites which have inherent tissue-specific molecular differences that obscure the underlying heterogeneity of inflammation $57,58,62,65$. By the exclusive use of ethmoid sinus mucosa for microarray, we recently identified gene expression profiles in three inflammatory endotypes; T1sNP, T2sNP and T3sNP, and predicted molecular mechanisms and biomarkers for each endotype ${ }^{55}$. The gene signatures suggested that T1sNP is associated with $\mathrm{T}$ cells (Th1 cells and $\mathrm{CD} 8^{+}$cytotoxic $\mathrm{T}$ cells), NK cells and antigen presenting cells (APC); T2sNP is associated with eosinophils, mast cells, basophils, Th2 cells, ILC2 and APC that are also found in T2wNP; and T3sNP is associated with neutrophils, Th17 cells, B cells and APC(see Figure 2) 55. We further found that T1 (CXCL9 and CXCL10), T2 (eosinophilic proteins and CCL26) and T3 (CSF3) endotypic biomarkers can distinguish tissue endotypes in nasal lavage fluids from patients with CRSsNP ${ }^{55}$.

Pathological mechanisms and their relationships to features and endotypes

As mentioned above, in Western countries, CRSwNP is primarily characterized by type 2 eosinophilic inflammation and mixed inflammatory histopathology, while both eosinophilic and non-eosinophilic patterns are 
found in polyps from Asian patients ${ }^{56,66}$. Interestingly, there has been a shift in the endotype distribution over time with an increase in the degree of eosinophilia observed in NPs from Asian patients ${ }^{67,68}$. Furthermore, recent research suggests that neutrophilic inflammation may also play a role in the pathogenesis of Western NP ${ }^{69}$. Thus, it is clear that inflammatory patterns in CRSwNP show geographic variability across Europe, Asia, and Oceania ${ }^{56}$. While the neutrophilic inflammatory endotype has been demonstrated in parts of Asia and Europe, evidence is accumulating that, at least in the Western countries, CRSsNP, like CRSwNP, has a predominantly type 2 eosinophilic pattern ${ }^{57,70}$.

Both innate and adaptive immune responses are important in the pathogenesis and endotypes of CRS. The NP tissue is characterized by dysregulated epithelium, elevated Th2 cells, innate lymphoid type 2 (ILC2) cells, B cells, mast cells, eosinophils, and basophils ${ }^{48-51,54,71,72}$. The sinonasal epithelium is the principal source of TSLP which is essential for type 2 inflammation and activates ILC2 cells and effector Th2 cells 45. Investigators around the world have demonstrated elevated thymic stromal lymphopoietin (TSLP) in eosinophilic NP tissue ${ }^{73-76}$. As already mentioned, Th2 and ILC2 are important sources of type 2 cytokines, including IL-4, 5, and $13{ }^{77}$. IL-5 promotes eosinophilic inflammation, and IL-4 and IL-13 activate isotype switching, mucus production, M2 macrophage differentiation, and remodeling in CRSwNP ${ }^{45}$. Type 2 inflammation is believed to drive NP formation by promoting fibrin deposition and retention of plasma proteins and edema ${ }^{33,78}$. In addition to expansion of Th2 and ILC2, B cells and plasmablasts are also increased and produce $\mathrm{IgE}$ and other immunoglobulins in NP tissue ${ }^{40,79}$. While CRSwNP is mainly type 2 (T2) in the West, some patients manifest type 1 (T1), type 3 (T3), or mixed inflammatory patterns with a combination of T1, T2, and T3 inflammation. T1 and T3 inflammation are associated with elevated IFN $\gamma$ and IL-17A, respectively. A subset of patients with CRS lacks an elevation of any T1, T2, or T3 markers and are classified as untypeable. This subgroup may represent another endotype of CRS whose inflammatory pattern is yet to be identified (see Figure 2) .

The three major inflammatory endotypes are also present in CRSsNP ${ }^{55,57,58}$. It was initially proposed that type 1 inflammation associated with elevated IFN- $\gamma$ was present in CRSsNP; however, this has not been confirmed in other studies ${ }^{40,57,80}$. Tan et al. investigated markers of inflammation in the ethmoid tissue from patients with CRS and controls and did not find a difference in IFN- $\gamma$ among CRSsNP, CRSwNP, and controls. Type 2 markers of inflammation, including ECP, IL-5, and IL-13, were highest in NP and ethmoid tissue from patients with $\mathrm{CRSwNP}^{57}$. Interestingly, T2 markers of inflammation were also significantly elevated in the ethmoid tissue from patients with CRSsNP compared to the ethmoid tissue from controls. Furthermore, IL-17A, the primary marker of T3 inflammation, was elevated in the ethmoid tissue of a subset of patients with CRSsNP. More recently, Kato and colleagues have demonstrated that gene expression in CRSsNP is reminiscent of that in CRSwNP. As in CRSwNP, in CRSsNP, T1 is associated with T cells (Th1 and $\mathrm{CD}^{+}$), NK cells, and antigen-presenting cells (APC), whereas T2 is associated with eosinophils, mast cells, Th2 cells, ILC2, and APCs and T3 CRSsNP is associated with Th17 cells, B cells, neutrophils, and $\mathrm{APCs}^{55}$. Wang et al. have also demonstrated that type 1 inflammation is predominant in Chinese patients from Beijing with CRSsNP, whereas patients from Chendgu, China, lack elevation of T1, T2, or T3 markers 56. Figure 2 shows a hypothetical overview of the inflammatory patterns of cells and responses as related to the three primary endotypes, independent of the phenotype (i.e. the presence or absence of polyps). We have adopted a shorthand that encompasses both endotype and the major phenotype. Type 2 CRSwNP is T2wNP in this scheme, while mixed type 1 and 3 CRSsNP would be T1,3sNP, etc. Figure 3 presents the pure and mixed endotypes and summarizes associated biomarkers. Occasionally, either CRSsNP or CRSwNP patients are identified that have all three endotypes elevated (T1,2,3sNP and $\mathrm{T} 1,2,3 \mathrm{wNP})$. The Tomassen paper identified 10 clusters/endotypes based on type 1 and 2 cytokines and inflammatory markers 43 . Clusters associated with low or no IL-5 resembled predominantly the CRSsNP phenotype and had a low likelihood of comorbid asthma. The highest IL-5 clusters were mostly CRSwNP patients expressing IgE to Staphylococcus aureusenterotoxins. One of their clusters expressed IL-17 and had a mixed CRSsNP/wNP phenotype.

Genomics, proteomics and metabolomics 
Modern techniques including genomics (transcriptomics), proteomics and metabolomics provide comprehensive and un-biased approaches to study biological systems, identify previously un-recognized mechanistic pathways in health and disease, and establish endotypes within a disease ${ }^{81-83}$. Systems biology has provided a more holistic understanding of diseases and endotypes ${ }^{81-83}$. Proteomic analysis of nasal mucus and mucosa in CRS suggested a trend of increased presence of immunological, metabolic, tissue remodeling and apoptotic pathways in CRS ${ }^{84,85}$. Metabolomics analysis of low molecular weight compounds (up to 1,500 Da) has been performed in CRS ${ }^{83}$. Fazlollahi et al. found that fatty acids (palmitic, oleic, stearic, and lauric) were highly elevated in CRSwNP compared to CRSsNP and control tissues ${ }^{86}$. Miyata found impaired synthesis of cyclooxygenase- and lipoxygenase-derived mediators (including prostaglandin $\mathrm{D}_{2}\left[\mathrm{PGD}_{2}\right], \mathrm{PGE}_{2}$, thromboxane $\mathrm{B}_{2}, 15$-hydroxyeicosatetraenoic acid and lipoxin $\mathrm{A}_{4}$ ) and selective upregulation of leukotriene $\mathrm{D} 4$ in nasal polyp-derived eosinophils compared to healthy peripheral blood eosinophils ${ }^{87}$. Future proteome and metabolome studies will require larger sample size and higher reproducibility to identify endotypes. In contrast, transcriptome analysis by microarray and RNA-Sequencing has been successfully used to characterize not only phenotype-specific (e.g. CRSsNP and CRSwNP) but also endotype-specific (e.g. eosinophilic and non-eosinophilic) gene expression profiles in CRS.

\section{AERD as an informative phenotypic variant}

As many as $15 \%$ of patients with CRSwNP have comorbid asthma and an intolerance to inhibitors of cyclooxygenase 1 (COX-1) ${ }^{88,89}$. This clinical triad is commonly referred to as Aspirin Exacerbated Respiratory Disease (AERD) in North America. The acronym NERD (NSAID Exacerbated Respiratory Disease) is often used in Europe but has not been adopted in North America as the word has negative connotations. While there is overlap between the phenotypes (and endotypes) of AERD and CRSwNP, important distinctions exist. AERD is the most severe sub-phenotype of CRSwNP. AERD patients typically have more severe sinonasal inflammation, their polyps grow quickly, and they undergo more sinus surgeries due to the recalcitrant nature of their disease ${ }^{89,90}$. Intolerance to COX-1 inhibitors has unique implications for clinical management of AERD. Aspirin desensitization followed by daily high-dose aspirin therapy can provide clinical benefit for patients with AERD but not for those with CRSwNP that tolerate COX-1 inhibitors ${ }^{91,92}$. AERD is predominantly characterized by type 2 inflammation. Studies are conflicting as to whether type 2 cytokine levels in AERD are similar or increased compared to CRSwNP, but levels are significantly elevated versus healthy controls ${ }^{77,93}$. In support of this, AERD patients clinically respond to type-2 biologics ${ }^{94,95}$ and, in some studies, even more so than patients with CRSwNP ${ }^{96}$. As with observations in CRSwNP and CRSsNP, Type 1 and type 3 endotypes have recently been described in AERD ${ }^{93,97}$. A dysregulation of arachidonic acid metabolism uniquely distinguishes pathogenesis of AERD from CRSwNP. AERD patients have a characteristic over-production of cysteinyl leukotrienes and $\mathrm{PGD}_{2}$ but reduced levels of $\mathrm{PGE}_{2}{ }^{98}$. AERD patients also have marked activation of the 15 Lipoxygenase pathway, now thought to be important in CRS. ${ }^{99,100}$ AERD patients with higher levels of urinary $\mathrm{PGD}_{2}$ may fail to tolerate an aspirin desensitization compared to patients with lower $\mathrm{PGD}_{2}$ levels, suggesting that sub-endotypes of AERD may also be present and clinically relevant ${ }^{101}$.

\section{Relating endotypes to phenotypes and clinical findings of disease}

Several groups have examined the association between endotypes and clinical phenotypes in CRS. In general, T2 inflammation is associated with NP (in the West) and asthma ${ }^{43,102}$. The type 2 eosinophilic inflammation is also associated with disease recurrence and severity in CRSsNP and CRSwNP 70,103,104. A study of the association between endotypes and phenotypes was conducted by Stevens et al., who examined inflammatory endotypes using markers including IFN- $\gamma$ (T1), eosinophilic cationic protein (T2), Charcot-Leyden crystal galectin (T2), and IL-17A (T3) in the ethmoid and NP tissue and related them to clinical parameters from medical and surgical records ${ }^{58}$. The T2 endotype was associated with the presence of NP, asthma comorbidity, smell loss, and allergic mucin in all CRS patients. The presence of pus was associated with the T3 endotype, and headache/migraine was negatively associated with the T1 endotype. When assessing patients with CRSsNP alone, smell loss and headache/migraine were associated with a T2 endotype, and the presence of pus was more common in T1 and T3 endotypes. Similarly, the T3 endotype was also associated 
with pus in patients with CRSwNP, and the T2 endotype tended to be associated with smell loss in patients with mixed endotypes. In contrast to the CRSsNP subgroup, headache/migraine was lower in the presence of T2 endotype in patients with CRSwNP ${ }^{58}$.Figure 4 summarizes the relationship between phenotype and endotype based on these findings.

A study using cluster analysis showed that older adults with CRS were more likely to have neutrophilic inflammation in the sinus tissue and elevated proinflammatory cytokines, IL-1 $\beta$, IL-9, TNF- $\alpha$, and IL-6 in the mucus compared to younger individuals with CRS ${ }^{105}$. The neutrophilic inflammatory pattern observed in older individuals was clinically associated with purulent drainage and a higher likelihood of bacteria. Potentially, these patients with predominantly neutrophilic inflammation are less likely to respond to corticosteroids or biologics and may respond to macrolides. Finally, elevated local $\operatorname{IgE}$ in NP tissue compared to control sinonasal tissue has been observed in patients with CRSwNP. Bachert and others have reported elevated levels of specific IgE (sIgE) against Staphylococcus aureus enterotoxins (SAE) in the NP tissue and systemic circulation ${ }^{106,107}$. The presence of SIgE to SAE has been associated with comorbid asthma and more severe sinonasal disease ${ }^{108,109}$.

\section{Associations between endotypes and responses to surgical and medical treatments}

Few studies have been performed evaluating the efficacy of specific treatments for CRS as a function of endotype. Outcome studies for CRS have generally not evaluated endotype prior to intervention, relying on phenotype to subdivide patients. Further, the definition of treatment success and the time point of evaluation post intervention have also been variable. Despite these limitations, some tentative statements can be made based on the presumed endotype of the population treated.

\section{Short-Term Broad-Spectrum Antibiotics}

Three and even six-week courses were recommended for CRSsNP prior to surgery for many years, based primarily on uncontrolled cohort studies ${ }^{110}$. Currently, no recommendation is made for or against the use of antibiotics for CRS, given the lack of placebo-controlled studies and avoidance of antibiotic overuse ${ }^{111-113}$. CRSsNP was historically presumed to be the result of infection or secondary to biofilms, anaerobes or intracellular pathogens ${ }^{13}$. Later work indicated alteration of the sinonasal microbiome rather than emergence of a specific pathogen ${ }^{14}$. Based on current dogma, the tissue endotype resulting from bacterial infection should presumably be T3, providing a theoretical rationale for the use of antibiotics in this setting(see Figure 2) ${ }^{40}$. More recent studies on CRSsNP in Chicago have indicated that slightly over $50 \%$ of CRSsNP patient tissues exhibit at least a partial $\mathrm{T} 2$ endotype $^{57}$. It is reasonable to expect that a properly selected group of CRS patients with T3 endotype, including polyp patients, would be more likely to respond to broad-spectrum antibiotics. A small prospective trial using 4 weeks of Augmentin documented objective and subjective improvement in the non-T2 CRS subset only ${ }^{114}$. It has also been proposed thatStaphylococcus aureus amplifies or causes T2 inflammation in a subset of CRS patients ${ }^{115-117}$, but studies documenting efficacy of anti-staphylococcal antibiotics in association with a reduction in this bacterium in the tissue have not been performed to date.

\section{Macrolides}

Macrolides exhibit immunomodulatory as well as antibiotic properties and some mixed evidence exists to support long-term use in selected CRS patients ${ }^{112,113}$. The presumed mechanism of action is the suppression of pro-inflammatory cytokines ${ }^{118-120}$ Two randomized, placebo-controlled trials have been performed in CRS. ${ }^{121,122}$ Post-hoc analysis of treatment response indicated that patients with low serum IgE (and presumably non T2) responded best and these responders exhibited decreased IL-8 levels in the mucus post treatment ${ }^{121}$. Later cohort studies demonstrated a lack of efficacy for macrolides in eosinophilic CRSwNP patients ${ }^{123,124}$. It remains to be established whether responders exhibit T1, T3, null or mixed endotypes. Studies of whether macrolides might have an additive effect with other medications (e.g. corticosteroids or a biologic) dedicated to suppressing T2 inflammation are worth pursuing ${ }^{125-127}$.

Doxycycline 
Doxycycline is an antibiotic that can also suppress cytokines, chemokines and remodeling factors ${ }^{128-131}$. Two small randomized controlled trials on Western CRSwNP patients (80-90\% T2) indicated modest polyp shrinkage and symptom improvement with doxycycline, possibly by preventing enhancement of T2 responses byStaphylococcus aureus ${ }^{71,132-134}$. Based on these data, a role for doxycycline in the management of T2 CRSwNP has been proposed. Mechanistic studies on doxycycline are unclear, however, and a later clinical study indicated that low T2 biomarkers in CRSwNP patients were predictors of a clinical response $\mathrm{e}^{135-137}$.

\section{Corticosteroids}

For many years, corticosteroids have been considered a mainstay of treatment for CRS. Corticosteroids have potent anti-inflammatory properties and suppress $\mathrm{T} 2$ inflammation greater than $\mathrm{T} 1$ and $\mathrm{T} 3$, possibly explaining their better efficacy in CRSwNP than CRSsNP ${ }^{138-141}$. In the case of T2 inflammation, corticosteroids suppress ILC2 cells, Th2 cells, basophils and eosinophils ${ }^{142-145}$. Neutrophils are relatively resistant to corticosteroid effects, however ${ }^{146,147}$. Reduced activity against T3 inflammation may explain the decreased corticosteroid responsiveness observed in clinical trials of Asian CRSwNP as well as CRSsNP in general versus Western CRSwNP66,147-154. Topical corticosteroid sprays have limited access to inflamed sinus tissue but high-volume steroid irrigations, improved delivery devices and steroid-impregnated implants have improved efficacy ${ }^{155-160}$. Epithelial barrier remodeling defects and basal cell hyperplasia induced by T2 inflammation are partially reversed by corticosteroids ${ }^{161,162}$. Barrier defects may reflect expansions of basal epithelial cells due to epigenetically determined events in T2 CRS and may increase antigen access, heightening inflammation $46,112,163$.

CRTH2 and Leukotriene Antagonists

A subset of AERD patients may express a discrete T2 subendotype with increased production of prostaglandin $\mathrm{D} 2\left(\mathrm{PGD}_{2}\right)$ and cysteinyl leukotrienes compared to aspirin-tolerant $\mathrm{T} 2 \mathrm{CRSwNP}{ }^{101}$. $\mathrm{PGD}_{2}$ activates the chemoattractant receptor-homologous molecule expressed on Th2 cells (CRTH2), which is important for eosinophil, basophil and lymphocyte recruitment and activation ${ }^{164}$. It is thus possible that CRTH2 and leukotriene antagonists could play a more significant role in managing patients with AERD compared to CRSwNP.

Surgery

Surgery is an option after failure of appropriate medical therapy ${ }^{113,165}$. Modern endoscopic sinus surgery (ESS) relieves sinus outflow obstruction, debrides inflamed tissue and provides improved access for topical agents ${ }^{166}$. Relief of obstruction is more relevant in mild to moderate CRSsNP ${ }^{4}$ and balloon dilation may be sufficient in selected cases ${ }^{167}$. Mucus stasis from obstruction promotes microbial overgrowth and infectious inflammation predominantly in non-polypoid T1,3 inflammation. Relieving obstruction is of less value in CRS cases with diffuse inflammation as in CRSwNP and severe CRSsNP, in particular when associated with T2 inflammation ${ }^{168,169}$. Although high-level data is lacking, more extensive surgical procedures such as a 'full house ESS' are typically recommended for these cases ${ }^{170-172}$. Maximum surgical approaches are reserved for the most severe cases and involve removal of the floor of the frontal sinus and in some cases sinus mucosa ${ }^{173-176}$. Surgical recurrence rates are generally correlated with the intensity of T2 tissue inflammation ${ }^{177-181}$. Systemic markers of T2 inflammation such as blood eosinophilia are associated with surgical failure even in the absence of a T2 signature in the tissue ${ }^{182}$. In non-eosinophilic CRS, limited available data suggests that higher intensity of T1 and T3 inflammation also favors surgical failure ${ }^{182,183}$.

\section{Monoclonal Biologics}

Biologic therapies targeting type 2 inflammation are increasingly used in patients with severe CRSwNP, which is associated with asthma comorbidity, worse disease severity, and recurrence after surgery (Table 1 ). Several monoclonal antibodies are either approved or under development for CRS. All inhibit aspects of T2 inflammation and have minimal side effects. Use of anti-T1 or T3 monoclonal antibodies for these respectively minor CRS endotypes (in the West) has not been attempted. Such treatment, if safe, might benefit patients with T1 or T3 endotypes, especially in Asia, where they are more prevalent. 
Dupilumab is a monoclonal antibody that blocks IL- 4 and IL-13 by binding to the $\alpha$ component of their shared receptors and inhibits T2 inflammation. In two phase 3 studies of only CRSwNP patients, SINUS-24 and SINUS-52, dupilumab reduced nasal polyp size, improved symptoms including nasal congestion and anosmia, and improved quality of life in patients with severe CRSwNP ${ }^{94}$. A pooled analysis of these studies showed that dupilumab reduced aggregate systemic corticosteroid use and nasal surgery by $76 \%$ compared to the placebo arm and substantially decreased type 2 inflammatory markers in serum and nasal secretions of patients with CRSwNP ${ }^{184}$. Based on these studies, dupilumab was approved for the treatment of inadequately controlled CRSwNP.

Omalizumab is a humanized monoclonal that selectively binds to the Ce3 domain of $\operatorname{IgE}$ and prevents $\operatorname{IgE}$ from binding to the high-affinity IgE receptor on mast cells and basophils ${ }^{185}$. Elevated local IgE is found in $\mathrm{NP}$ and is associated with local eosinophilic inflammation, severe NP, and comorbid asthma ${ }^{11,43,49,72,79,106}$ - The POLYP 1 and POLYP 2 phase 3 trials found that omalizumab reduced polyp size and improved sinonasal symptoms and quality of life in patients with CRSwNP ${ }^{95}$.

Mepolizumab is a monoclonal antibody that inhibits IL-5, the cytokine that is key in promoting eosinophil recruitment, activation and survival. Phase 3 trials have demonstrated subjective and objective efficacy and FDA approval for CRSwNP is expected late in 2021. (ClinicalTrials.gov. NCT0308579). Benralizumab is a cytotoxic monoclonal antibody targeting the IL-5 receptor that eliminates eosinophils and has undergone Phase 3 trials for CRSwNP (ClinicalTrials.gov. NCT03401229). The completed phase 3 trials reportedly met their primary endpoints at the time of this review.

Overall, although the monoclonal antibodies above are effective drugs that target key elements of T2 inflammation, their efficacy relative to each-other is presently unclear. T2 sub-endotypes likely exist, based upon anecdotal reports of variable response to these monoclonal antibodies. Intuitively, patients with eosinophildriven disease should respond best to mepolizumab or benralizumab, while patients with disease driven by mast cells and IgE should respond best to omalizumab and perhaps dupilumab; no head-to-head trials have been performed, and no strong recommendations can be made as to which biologic to use first in a patient with T2 disease. Nonetheless, expert panels have made some recommendations for clinicians ${ }^{186}$. There is the untested impression that dupilumab has the greatest objective efficacy and highest response rate of the currently available $\mathrm{T} 2$ targeting monoclonal antibodies.

The success of T2 biologics in CRSwNP established the importance of endotype targeted therapy in difficult to treat NP. Use of these drugs is only approved in T2 polyp patients with established endotype. The use of mucus samples to determine endotype is under development. Currently, the presence of asthma, AERD

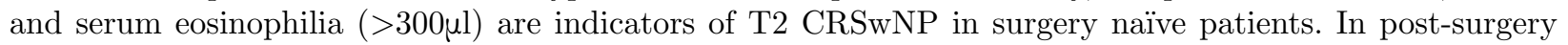
patients, eosinophilic histology is definitive. T2 biologics are indicated for CRSwNP with severe symptoms despite INS and more than one oral prednisone burst per year. Questions remain about whether these drugs should be used in patients that have not undergone surgery as the surgical revision rate at 5 years is only approximately $20 \%{ }^{187-189}$. While these drugs are effective, QOL does not return to normal, and polyposis does not completely resolve ${ }^{94}$. The most effective and practical treatment regimen for high risk, multirecurrent patients may be surgery followed by a planned post-operative biologic agent to prevent recurrence and further reduce symptom burden.

\section{Summary and conclusions}

Understanding the basis of widespread heterogeneity in the manifestations of CRS is advanced by findings that the three main endotypes, T1, T2 and T3, orchestrate the expression of three distinct large sets of genes. It is clear that T2 inflammation can be found around the world and in both CRSwNP and CRSsNP phenotypes. Although the prevalence of T2 endotype in Asia was very low decades ago, it is increasing with industrialization. Another emerging view is that endotype, rather than the phenotype, can drive clinical features, such as the presence of comorbid asthma (T2sNP and T2wNP) and pus (T3sNP and T3wNP). Drugs blocking T2 inflammation can shrink nasal polyps in western countries; as trials are initiated in T2sNP patients, we expect that this very large group of patients will be found to benefit from blockade 
of type 2 inflammation. Studies of the microbiome may discover that the higher prevalence of T3 forms of CRS in China reflect distinct microbiological exposures. The development and use of improved methods of endotyping disease in the clinic will likely usher in expansion of the use of biological therapies targeting T2 and introduction of treatments targeting other endotypes.

\section{Acknowledgments}

This research was supported in part by NIH grants, R01 AI137174, K23 AI141694, U19 AI106683 and P01 AI145818 and by a grant from the Ernest S. Bazley Foundation.

\section{References}

1. Hsu J, Avila PC, Kern RC, Hayes MG, Schleimer RP, Pinto JM. Genetics of chronic rhinosinusitis: state of the field and directions forward.J Allergy Clin Immunol. 2013;131(4):977-993, 993 e971-975.

2. Stevens WW, Lee RJ, Schleimer RP, Cohen NA. Chronic rhinosinusitis pathogenesis. J Allergy Clin Immunol. 2015;136(6):1442-1453.

3. Gudis D, Zhao KQ, Cohen NA. Acquired cilia dysfunction in chronic rhinosinusitis. Am J Rhinol Allergy. 2012;26(1):1-6.

4. Stammberger H, Posawetz W. Functional endoscopic sinus surgery. Concept, indications and results of the Messerklinger technique.Eur Arch Otorhinolaryngol. 1990;247(2):63-76.

5. Song WJ, Lee JH, Won HK, Bachert C. Chronic Rhinosinusitis with Nasal Polyps in Older Adults: Clinical Presentation, Pathophysiology, and Comorbidity. Curr Allergy Asthma Rep. 2019;19(10):46.

6. Chang EH, Stern DA, Willis AL, Guerra S, Wright AL, Martinez FD. Early life risk factors for chronic sinusitis: A longitudinal birth cohort study. J Allergy Clin Immunol. 2018;141(4):1291-1297 e1292.

7. DelGaudio JM, Loftus PA, Hamizan AW, Harvey RJ, Wise SK. Central compartment atopic disease. Am $J$ Rhinol Allergy.2017;31(4):228-234.

8. Bacciu A, Buzio C, Giordano D, et al. Nasal polyposis in Churg-Strauss syndrome. Laryngoscope. 2008;118(2):325-329.

9. Ocampo CJ, Peters AT. Antibody deficiency in chronic rhinosinusitis: epidemiology and burden of illness. Am J Rhinol Allergy.2013;27(1):34-38.

10. Ponikau JU, Sherris DA, Kern EB, et al. The diagnosis and incidence of allergic fungal sinusitis. Mayo Clin Proc. 1999;74(9):877-884.

11. Bachert C, Gevaert P, Holtappels G, Johansson SG, van Cauwenberge P. Total and specific IgE in nasal polyps is related to local eosinophilic inflammation. J Allergy Clin Immunol. 2001;107(4):607-614.

12. Perloff JR, Palmer JN. Evidence of bacterial biofilms on frontal recess stents in patients with chronic rhinosinusitis. Am J Rhinol. 2004;18(6):377-380.

13. Kern RC, Conley DB, Walsh W, et al. Perspectives on the etiology of chronic rhinosinusitis: an immune barrier hypothesis. Am J Rhinol. 2008;22(6):549-559.

14. Abreu NA, Nagalingam NA, Song Y, et al. Sinus microbiome diversity depletion and Corynebacterium tuberculostearicum enrichment mediates rhinosinusitis. Sci Transl Med. 2012;4(151):151ra124.

15. Tan BK, Lu G, Kwasny MJ, et al. Effect of symptom-based risk stratification on the costs of managing patients with chronic rhinosinusitis symptoms. Int Forum Allergy Rhinol.2013;3(11):933-940.

16. Akdis CA, Bachert C, Cingi C, et al. Endotypes and phenotypes of chronic rhinosinusitis: a PRACTALL document of the European Academy of Allergy and Clinical Immunology and the American Academy of Allergy, Asthma \& Immunology. J Allergy Clin Immunol.2013;131(6):1479-1490. 
17. Harlin SL, Ansel DG, Lane SR, Myers J, Kephart GM, Gleich GJ. A clinical and pathologic study of chronic sinusitis: the role of the eosinophil. J Allergy Clin Immunol. 1988;81(5 Pt 1):867-875.

18. Stoop AE, van der Heijden HA, Biewenga J, van der Baan S. Eosinophils in nasal polyps and nasal mucosa: an immunohistochemical study. J Allergy Clin Immunol. 1993;91(2):616-622.

19. Jankowski R, Bene MC, Moneret-Vautrin AD, et al. Immunohistological characteristics of nasal polyps. A comparison with healthy mucosa and chronic sinusitis. Rhinol Suppl. 1989;8:51-58.

20. Mygind N. Nasal polyposis. J Allergy Clin Immunol. 1990;86(6 Pt 1):827-829.

21. Fokkens WJ, Holm AF, Rijntjes E, Mulder PG, Vroom TM. Characterization and quantification of cellular infiltrates in nasal mucosa of patients with grass pollen allergy, non-allergic patients with nasal polyps and controls. Int Arch Allergy Appl Immunol.1990;93(1):66-72.

22. Drake-Lee A, Price J. Mast cell ultrastructure in the inferior turbinate and stroma of nasal polyps. $J$ Laryngol Otol.1997;111(4):340-345.

23. Polzehl D, Moeller P, Riechelmann H, Perner S. Distinct features of chronic rhinosinusitis with and without nasal polyps. Allergy.2006;61(11):1275-1279.

24. Huvenne W, van Bruaene N, Zhang N, et al. Chronic rhinosinusitis with and without nasal polyps: what is the difference? Curr Allergy Asthma Rep. 2009;9(3):213-220.

25. Sobol SE, Christodoulopoulos P, Manoukian JJ, et al. Cytokine profile of chronic sinusitis in patients with cystic fibrosis.Arch Otolaryngol Head Neck Surg. 2002;128(11):1295-1298.

26. Soler ZM, Sauer D, Mace J, Smith TL. Impact of mucosal eosinophilia and nasal polyposis on qualityof-life outcomes after sinus surgery. Otolaryngol Head Neck Surg. 2010;142(1):64-71.

27. Stierna P, Carlsoo B. Histopathological observations in chronic maxillary sinusitis. Acta Otolaryngol. 1990;110(5-6):450-458.

28. Berger G, Kattan A, Bernheim J, Ophir D. Polypoid mucosa with eosinophilia and glandular hyperplasia in chronic sinusitis: a histopathological and immunohistochemical study. Laryngoscope.2002;112(4):738-745.

29. Malekzadeh S, McGuire JF. The new histologic classification of chronic rhinosinusitis. Curr Allergy Asthma Rep.2003;3(3):221-226.

30. Kuhar HN, Tajudeen BA, Heilingoetter A, et al. Distinct histopathologic features of radiation-induced chronic sinusitis.Int Forum Allergy Rhinol. 2017;7(10):990-998.

31. Brescia G, Alessandrini L, Marioni G. Structured histopathology for endotyping and planning rational treatment in chronic rhinosinusitis. Am J Otolaryngol. 2021;42(1):102795.

32. Takabayashi T, Kato A, Peters AT, et al. Excessive fibrin deposition in nasal polyps caused by fibrinolytic impairment through reduction of tissue plasminogen activator expression. Am J Respir Crit Care Med. 2013;187(1):49-57.

33. Takabayashi T, Kato A, Peters AT, et al. Increased expression of factor XIII-A in patients with chronic rhinosinusitis with nasal polyps.J Allergy Clin Immunol. 2013.

34. Chen CL, Yao Y, Pan L, et al. Common fibrin deposition and tissue plasminogen activator downregulation in nasal polyps with distinct inflammatory endotypes. J Allergy Clin Immunol.2020;146(3):677-681.

35. Bachert C, Wagenmann M, Hauser U, Rudack C. IL-5 synthesis is upregulated in human nasal polyp tissue. J Allergy Clin Immunol.1997;99(6 Pt 1):837-842.

36. Bachert C, Wagenmann M, Rudack C, et al. The role of cytokines in infectious sinusitis and nasal polyposis. Allergy.1998;53(1):2-13. 
37. Takeuchi K, Yuta A, Sakakura Y. Interleukin-8 gene expression in chronic sinusitis. Am J Otolaryngol. 1995;16(2):98-102.

38. Suzuki H, Takahashi Y, Wataya H, et al. Mechanism of neutrophil recruitment induced by IL-8 in chronic sinusitis. J Allergy Clin Immunol. 1996;98(3):659-670.

39. Riechelmann H, Deutschle T, Rozsasi A, Keck T, Polzehl D, Burner H. Nasal biomarker profiles in acute and chronic rhinosinusitis. Clin Exp Allergy. 2005;35(9):1186-1191.

40. Van Zele T, Claeys S, Gevaert P, et al. Differentiation of chronic sinus diseases by measurement of inflammatory mediators. Allergy.2006;61(11):1280-1289.

41. Cao PP, Li HB, Wang BF, et al. Distinct immunopathologic characteristics of various types of chronic rhinosinusitis in adult Chinese. J Allergy Clin Immunol. 2009;124(3):478-484, 484 e471-472.

42. Zhang N, Van Zele T, Perez-Novo C, et al. Different types of T-effector cells orchestrate mucosal inflammation in chronic sinus disease. J Allergy Clin Immunol. 2008;122(5):961-968.

43. Tomassen P, Vandeplas G, Van Zele T, et al. Inflammatory endotypes of chronic rhinosinusitis based on cluster analysis of biomarkers.J Allergy Clin Immunol. 2016;137(5):1449-1456 e1444.

44. Bachert C, Akdis CA. Phenotypes and Emerging Endotypes of Chronic Rhinosinusitis. J Allergy Clin Immunol Pract. 2016;4(4):621-628.

45. Kato A. Immunopathology of chronic rhinosinusitis. Allergol Int. 2015;64(2):121-130.

46. Schleimer RP. Immunopathogenesis of Chronic Rhinosinusitis and Nasal Polyposis. Annu Rev Pathol. 2017;12:331-357.

47. Peterson S, Poposki JA, Nagarkar DR, et al. Increased expression of CC chemokine ligand 18 in patients with chronic rhinosinusitis with nasal polyps. J Allergy Clin Immunol. 2012;129(1):119-127 e111-119.

48. Takabayashi T, Kato A, Peters AT, et al. Glandular mast cells with distinct phenotype are highly elevated in chronic rhinosinusitis with nasal polyps. J Allergy Clin Immunol. 2012;130(2):410-420 e415.

49. Hulse KE, Norton JE, Suh L, et al. Chronic rhinosinusitis with nasal polyps is characterized by B-cell inflammation and EBV-induced protein 2 expression. J Allergy Clin Immunol. 2013;131(4):1075-1083, 1083 e1071-1077.

50. Derycke L, Eyerich S, Van Crombruggen K, et al. Mixed T helper cell signatures in chronic rhinosinusitis with and without polyps. PLoS One. 2014;9(6):e97581.

51. Mahdavinia M, Carter RG, Ocampo CJ, et al. Basophils are elevated in nasal polyps of patients with chronic rhinosinusitis without aspirin sensitivity. J Allergy Clin Immunol. 2014;133(6):1759-1763.

52. Shi LL, Song J, Xiong P, et al. Disease-specific T-helper cell polarizing function of lesional dendritic cells in different types of chronic rhinosinusitis with nasal polyps. Am J Respir Crit Care Med. 2014;190(6):628638.

53. Poposki JA, Peterson S, Welch K, et al. Elevated presence of myeloid dendritic cells in nasal polyps of patients with chronic rhinosinusitis. Clin Exp Allergy. 2015;45(2):384-393.

54. Poposki JA, Klingler AI, Tan BK, et al. Group 2 innate lymphoid cells are elevated and activated in chronic rhinosinusitis with nasal polyps. Immun Inflamm Dis. 2017;5(3):233-243.

55. Klingler AI, Stevens WW, Tan BK, et al. Mechanisms and biomarkers of inflammatory endotypes in chronic rhinosinusitis without nasal polyps.J Allergy Clin Immunol. 2020.

56. Wang X, Zhang N, Bo M, et al. Diversity of TH cytokine profiles in patients with chronic rhinosinusitis: A multicenter study in Europe, Asia, and Oceania. J Allergy Clin Immunol. 2016;138(5):1344-1353. 
57. Tan BK, Klingler AI, Poposki JA, et al. Heterogeneous inflammatory patterns in chronic rhinosinusitis without nasal polyps in Chicago, Illinois. J Allergy Clin Immunol. 2017;139(2):699-703 e697.

58. Stevens WW, Peters AT, Tan BK, et al. Associations Between Inflammatory Endotypes and Clinical Presentations in Chronic Rhinosinusitis. J Allergy Clin Immunol Pract. 2019;7(8):2812-2820 e2813.

59. Baba S, Kondo K, Toma-Hirano M, et al. Local increase in IgE and class switch recombination to IgE in nasal polyps in chronic rhinosinusitis. Clin Exp Allergy. 2014;44(5):701-712.

60. Plager DA, Kahl JC, Asmann YW, et al. Gene transcription changes in asthmatic chronic rhinosinusitis with nasal polyps and comparison to those in atopic dermatitis. PLoS One. 2010;5(7):e11450.

61. Tyler MA, Russell CB, Smith DE, et al. Large-scale gene expression profiling reveals distinct type 2 inflammatory patterns in chronic rhinosinusitis subtypes. J Allergy Clin Immunol.2017;139(3):1061-1064 e1064.

62. Wang W, Gao Z, Wang H, et al. Transcriptome Analysis Reveals Distinct Gene Expression Profiles in Eosinophilic and Noneosinophilic Chronic Rhinosinusitis with Nasal Polyps. Sci Rep. 2016;6:26604.

63. Okada N, Nakayama T, Asaka D, et al. Distinct gene expression profiles and regulation networks of nasal polyps in eosinophilic and non-eosinophilic chronic rhinosinusitis. Int Forum Allergy Rhinol. 2018;8(5):592604.

64. Ryu G, Mo JH, Shin HW. Epithelial-to-mesenchymal transition in neutrophilic chronic rhinosinusitis. Curr Opin Allergy Clin Immunol. 2021;21(1):30-37.

65. Seshadri S, Rosati M, Lin DC, et al. Regional differences in the expression of innate host defense molecules in sinonasal mucosa. J Allergy Clin Immunol. 2013;132(5):1227-1230 e1225.

66. Wen W, Liu W, Zhang L, et al. Increased neutrophilia in nasal polyps reduces the response to oral corticosteroid therapy. J Allergy Clin Immunol. 2012;129(6):1522-1528 e1525.

67. Katotomichelakis M, Tantilipikorn P, Holtappels G, et al. Inflammatory patterns in upper airway disease in the same geographical area may change over time. Am J Rhinol Allergy.2013;27(5):354-360.

68. Kim SJ, Lee KH, Kim SW, Cho JS, Park YK, Shin SY. Changes in histological features of nasal polyps in a Korean population over a 17-year period. Otolaryngol Head Neck Surg. 2013;149(3):431-437.

69. Delemarre T, Holtappels G, De Ruyck N, et al. A substantial neutrophilic inflammation as regular part of severe type 2 chronic rhinosinusitis with nasal polyps. J Allergy Clin Immunol. 2020.

70. Delemarre T, Holtappels G, De Ruyck N, et al. Type 2 inflammation in chronic rhinosinusitis without nasal polyps: Another relevant endotype.J Allergy Clin Immunol. 2020;146(2):337-343 e336.

71. Van Zele T, Gevaert P, Holtappels G, van Cauwenberge P, Bachert C. Local immunoglobulin production in nasal polyposis is modulated by superantigens. Clin Exp Allergy. 2007;37(12):1840-1847.

72. Buchheit KM, Dwyer DF, Ordovas-Montanes J, et al. IL-5Ralpha marks nasal polyp IgG4- and IgEexpressing cells in aspirin-exacerbated respiratory disease. J Allergy Clin Immunol.2020;145(6):1574-1584.

73. Nagarkar DR, Poposki JA, Tan BK, et al. Thymic stromal lymphopoietin activity is increased in nasal polyps of patients with chronic rhinosinusitis. J Allergy Clin Immunol. 2013;132(3):593-600 e512.

74. Liu T, Li TL, Zhao F, et al. Role of thymic stromal lymphopoietin in the pathogenesis of nasal polyposis. Am J Med Sci.2011;341(1):40-47.

75. Boita M, Garzaro M, Raimondo L, et al. Eosinophilic inflammation of chronic rhinosinusitis with nasal polyps is related to OX40 ligand expression. Innate Immun. 2015;21(2):167-174. 
76. Ogasawara N, Klingler AI, Tan BK, et al. Epithelial activators of type 2 inflammation: Elevation of thymic stromal lymphopoietin, but not IL-25 or IL-33, in chronic rhinosinusitis with nasal polyps in Chicago, Illinois. Allergy. 2018;73(11):2251-2254.

77. Stevens WW, Ocampo CJ, Berdnikovs S, et al. Cytokines in Chronic Rhinosinusitis. Role in Eosinophilia and Aspirin-exacerbated Respiratory Disease. Am J Respir Crit Care Med. 2015;192(6):682-694.

78. Takabayashi T, Schleimer RP. Formation of nasal polyps: The roles of innate type 2 inflammation and deposition of fibrin. J Allergy Clin Immunol. 2020;145(3):740-750.

79. Feldman S, Kasjanski R, Poposki J, et al. Chronic airway inflammation provides a unique environment for B cell activation and antibody production. Clin Exp Allergy. 2017;47(4):457-466.

80. Van Bruaene N, Perez-Novo CA, Basinski TM, et al. T-cell regulation in chronic paranasal sinus disease. $J$ Allergy Clin Immunol.2008;121(6):1435-1441, 1441 e1431-1433.

81. Pinu FR, Beale DJ, Paten AM, et al. Systems Biology and Multi-Omics Integration: Viewpoints from the Metabolomics Research Community. Metabolites. 2019;9(4).

82. Veenstra TD. Systems Biology: Current Progress and Future Outlook.Proteomics. 2020:e2000235.

83. Michalik M, Samet A, Dmowska-Koroblewska A, et al. An Overview of the Application of Systems Biology in an Understanding of Chronic Rhinosinusitis (CRS) Development. J Pers Med. 2020;10(4).

84. Kao SS, Bassiouni A, Ramezanpour M, et al. Scoping review of chronic rhinosinusitis proteomics. Rhinology. 2020;58(5):418-429.

85. Kao SS, Bassiouni A, Ramezanpour M, et al. Proteomic analysis of nasal mucus samples of healthy patients and patients with chronic rhinosinusitis. J Allergy Clin Immunol. 2021;147(1):168-178.

86. Fazlollahi F, Kongmanas K, Tanphaichitr N, et al. Lipidomic profiling of sinus mucosa from patients with chronic rhinosinusitis. Clin Transl Sci. 2015;8(2):107-115.

87. Miyata J, Fukunaga K, Kawashima Y, et al. Dysregulated fatty acid metabolism in nasal polyp-derived eosinophils from patients with chronic rhinosinusitis. Allergy. 2019;74(6):1113-1124.

88. Rajan JP, Wineinger NE, Stevenson DD, White AA. Prevalence of aspirin-exacerbated respiratory disease among asthmatic patients: A meta-analysis of the literature. J Allergy Clin Immunol.2015;135(3):676-681 e671.

89. Stevens WW, Peters AT, Hirsch AG, et al. Clinical Characteristics of Patients with Chronic Rhinosinusitis with Nasal Polyps, Asthma, and Aspirin-Exacerbated Respiratory Disease. J Allergy Clin Immunol Pract. 2017;5(4):1061-1070 e1063.

90. White AA, Stevenson DD. Aspirin-Exacerbated Respiratory Disease. N Engl J Med. 2018;379(11):10601070 .

91. Kowalski ML, Agache I, Bavbek S, et al. Diagnosis and management of NSAID-Exacerbated Respiratory Disease (N-ERD)-a EAACI position paper.Allergy. 2019;74(1):28-39.

92. Stevens WW, Jerschow E, Baptist AP, et al. The role of aspirin desensitization followed by oral aspirin therapy in managing patients with aspirin-exacerbated respiratory disease: A Work Group Report from the Rhinitis, Rhinosinusitis and Ocular Allergy Committee of the American Academy of Allergy, Asthma \& Immunology. J Allergy Clin Immunol. 2020.

93. Scott WC, Cahill KN, Milne GL, et al. Inflammatory heterogeneity in aspirin-exacerbated respiratory disease. J Allergy Clin Immunol.2020.

94. Bachert C, Han JK, Desrosiers M, et al. Efficacy and safety of dupilumab in patients with severe chronic rhinosinusitis with nasal polyps (LIBERTY NP SINUS-24 and LIBERTY NP SINUS-52): results 
from two multicentre, randomised, double-blind, placebo-controlled, parallel-group phase 3 trials. Lancet. 2019;394(10209):1638-1650.

95. Gevaert P, Omachi TA, Corren J, et al. Efficacy and safety of omalizumab in nasal polyposis: 2 randomized phase 3 trials. J Allergy Clin Immunol. 2020;146(3):595-605.

96. Laidlaw TM, Mullol J, Fan C, et al. Dupilumab improves nasal polyp burden and asthma control in patients with CRSwNP and AERD. J Allergy Clin Immunol Pract. 2019;7(7):2462-2465 e2461.

97. Jakiela B, Soja J, Sladek K, et al. Heterogeneity of lower airway inflammation in patients with NSAIDexacerbated respiratory disease.J Allergy Clin Immunol. 2020.

98. Laidlaw TM, Boyce JA. Aspirin-Exacerbated Respiratory Disease-New Prime Suspects. $N$ Engl J Med. 2016;374(5):484-488.

99. Stevens WW, Staudacher AG, Hulse KE, et al. Activation of the 15-lipoxygenase pathway in aspirinexacerbated respiratory disease.J Allergy Clin Immunol. 2021;147(2):600-612.

100. Kristjansson RP, Benonisdottir S, Davidsson OB, et al. A loss-of-function variant in ALOX15 protects against nasal polyps and chronic rhinosinusitis. Nat Genet. 2019;51(2):267-276.

101. Cahill KN, Bensko JC, Boyce JA, Laidlaw TM. Prostaglandin D(2): a dominant mediator of aspirinexacerbated respiratory disease. J Allergy Clin Immunol. 2015;135(1):245-252.

102. Wang M, Bu X, Luan G, et al. Distinct type 2-high inflammation associated molecular signatures of chronic rhinosinusitis with nasal polyps with comorbid asthma. Clin Transl Allergy. 2020;10:26.

103. Szucs E, Ravandi S, Goossens A, Beel M, Clement PA. Eosinophilia in the ethmoid mucosa and its relationship to the severity of inflammation in chronic rhinosinusitis. Am J Rhinol. 2002;16(3):131-134.

104. Kountakis SE, Arango P, Bradley D, Wade ZK, Borish L. Molecular and cellular staging for the severity of chronic rhinosinusitis. Laryngoscope. 2004;114(11):1895-1905.

105. Morse JC, Li P, Ely KA, et al. Chronic rhinosinusitis in elderly patients is associated with an exaggerated neutrophilic proinflammatory response to pathogenic bacteria. J Allergy Clin Immunol.2019;143(3):990-1002 e1006.

106. Van Zele T, Gevaert P, Watelet JB, et al. Staphylococcus aureus colonization and IgE antibody formation to enterotoxins is increased in nasal polyposis. J Allergy Clin Immunol. 2004;114(4):981-983.

107. Tripathi A, Kern R, Conley DB, et al. Staphylococcal exotoxins and nasal polyposis: analysis of systemic and local responses. Am J Rhinol. 2005;19(4):327-333.

108. Bachert C, Zhang N, Holtappels G, et al. Presence of IL-5 protein and IgE antibodies to staphylococcal enterotoxins in nasal polyps is associated with comorbid asthma. J Allergy Clin Immunol.2010;126(5):962968, 968 e961-966.

109. Jonstam K, Westman M, Holtappels G, Holweg CTJ, Bachert C. Serum periostin, IgE, and SE-IgE can be used as biomarkers to identify moderate to severe chronic rhinosinusitis with nasal polyps. J Allergy Clin Immunol. 2017;140(6):1705-1708 e1703.

110. Soler ZM, Oyer SL, Kern RC, et al. Antimicrobials and chronic rhinosinusitis with or without polyposis in adults: an evidenced-based review with recommendations. Int Forum Allergy Rhinol.2013;3(1):31-47.

111. Smith SS, Evans CT, Tan BK, Chandra RK, Smith SB, Kern RC. National burden of antibiotic use for adult rhinosinusitis. J Allergy Clin Immunol. 2013;132(5):1230-1232.

112. Fokkens WJ, Lund VJ, Hopkins C, et al. European Position Paper on Rhinosinusitis and Nasal Polyps 2020. Rhinology. 2020;58(Suppl S29):1-464. 
113. Orlandi RR, Kingdom TT, Smith TL, et al. International consensus statement on allergy and rhinology: rhinosinusitis 2021. Int Forum Allergy Rhinol. 2021;11(3):213-739.

114. Gunel C, Bleier BS, Meteoglu I. Antibiotics in eosinophilic chronic rhinosinusitis: Rethinking maximal antimicrobial medical therapy.Laryngoscope. 2017;127(4):794-796.

115. Bachert C, Gevaert P, Zhang N, van Zele T, Perez-Novo C. Role of staphylococcal superantigens in airway disease. Chem Immunol Allergy. 2007;93:214-236.

116. Lan F, Zhang N, Holtappels G, et al. Staphylococcus aureus Induces a Mucosal Type 2 Immune Response via Epithelial Cell-derived Cytokines. Am J Respir Crit Care Med. 2018;198(4):452-463.

117. Bachert C, Holtappels G, Merabishvili M, et al. Staphylococcus aureus controls interleukin-5 release in upper airway inflammation.J Proteomics. 2018;180:53-60.

118. Suzuki H, Shimomura A, Ikeda K, Oshima T, Takasaka T. Effects of long-term low-dose macrolide administration on neutrophil recruitment and IL-8 in the nasal discharge of chronic sinusitis patients. Tohoku J Exp Med. 1997;182(2):115-124.

119. Culic O, Erakovic V, Parnham MJ. Anti-inflammatory effects of macrolide antibiotics. Eur J Pharmacol. 2001;429(1-3):209-229.

120. Healy DP. Macrolide immunomodulation of chronic respiratory diseases. Curr Infect Dis Rep. 2007;9(1):7-13.

121. Wallwork B, Coman W, Mackay-Sim A, Greiff L, Cervin A. A double-blind, randomized, placebocontrolled trial of macrolide in the treatment of chronic rhinosinusitis. Laryngoscope.2006;116(2):189-193.

122. Videler WJ, Badia L, Harvey RJ, et al. Lack of efficacy of long-term, low-dose azithromycin in chronic rhinosinusitis: a randomized controlled trial. Allergy. 2011;66(11):1457-1468.

123. Haruna S, Shimada C, Ozawa M, Fukami S, Moriyama H. A study of poor responders for long-term, low-dose macrolide administration for chronic sinusitis. Rhinology. 2009;47(1):66-71.

124. Bezerra TFP, Pezato R, de Barros PM, et al. Prospective evaluation of clarithromycin in recurrent chronic rhinosinusitis with nasal polyps.Braz J Otorhinolaryngol. 2019.

125. Huang Z, Zhou B. Clarithromycin for the treatment of adult chronic rhinosinusitis: a systematic review and meta-analysis. Int Forum Allergy Rhinol. 2019;9(5):545-555.

126. Oakley GM, Harvey RJ, Lund VJ. The Role of Macrolides in Chronic Rhinosinusitis (CRSsNP and CRSwNP). Curr Allergy Asthma Rep.2017;17(5):30.

127. Seresirikachorn K, Suwanparin N, Srisunthornphanich C, Chitsuthipakorn W, Kanjanawasee D, Snidvongs K. Factors of success of low-dose macrolides in chronic sinusitis: Systematic review and meta-analysis. Laryngoscope. 2019;129(7):1510-1519.

128. Lees KA, Orlandi RR, Oakley G, Alt JA. The Role of Macrolides and Doxycycline in Chronic Rhinosinusitis. Immunol Allergy Clin North Am. 2020;40(2):303-315.

129. Henehan M, Montuno M, De Benedetto A. Doxycycline as an anti-inflammatory agent: updates in dermatology. J Eur Acad Dermatol Venereol. 2017;31(11):1800-1808.

130. Gueders MM, Bertholet P, Perin F, et al. A novel formulation of inhaled doxycycline reduces allergeninduced inflammation, hyperresponsiveness and remodeling by matrix metalloproteinases and cytokines modulation in a mouse model of asthma. Biochem Pharmacol. 2008;75(2):514-526.

131. Kuzin, II, Snyder JE, Ugine GD, et al. Tetracyclines inhibit activated B cell function. Int Immunol. 2001;13(7):921-931. 
132. Van Zele T, Gevaert P, Holtappels G, et al. Oral steroids and doxycycline: two different approaches to treat nasal polyps. J Allergy Clin Immunol. 2010;125(5):1069-1076 e1064.

133. De Schryver E, Derycke L, Calus L, et al. The effect of systemic treatments on periostin expression reflects their interference with the eosinophilic inflammation in chronic rhinosinusitis with nasal polyps.Rhinology. 2017;55(2):152-160.

134. Grammer LC. Doxycycline or oral corticosteroids for nasal polyps.J Allergy Clin Immunol Pract. 2013;1(5):541-542.

135. Cardell LO, Stjarne P, Jonstam K, Bachert C. Endotypes of chronic rhinosinusitis: Impact on management. J Allergy Clin Immunol.2020;145(3):752-756.

136. Pinto Bezerra Soter AC, Bezerra TF, Pezato R, et al. Prospective open-label evaluation of long-term low-dose doxycycline for difficult-to-treat chronic rhinosinusitis with nasal polyps. Rhinology. 2017;55(2):175180.

137. Sommer JU, Schultz JD, Grossbaier J, Stern-Straeter J, Hormann K, Sauter A. In vitro effects of doxycycline on inflammatory cytokines and gelatinases in chronic rhinosinusitis. In Vivo.2012;26(3):369-374.

138. Banuelos J, Lu NZ. A gradient of glucocorticoid sensitivity among helper T cell cytokines. Cytokine Growth Factor Rev.2016;31:27-35.

139. Raundhal M, Morse C, Khare A, et al. High IFN-gamma and low SLPI mark severe asthma in mice and humans. J Clin Invest.2015;125(8):3037-3050.

140. Halwani R, Al-Muhsen S, Hamid Q. T helper 17 cells in airway diseases: from laboratory bench to bedside. Chest.2013;143(2):494-501.

141. Strehl C, Ehlers L, Gaber T, Buttgereit F. Glucocorticoids-All-Rounders Tackling the Versatile Players of the Immune System. Front Immunol. 2019;10:1744.

142. Belvisi MG. Regulation of inflammatory cell function by corticosteroids. Proc Am Thorac Soc. 2004;1(3):207-214.

143. Walford HH, Lund SJ, Baum RE, et al. Increased ILC2s in the eosinophilic nasal polyp endotype are associated with corticosteroid responsiveness. Clin Immunol. 2014;155(1):126-135.

144. Doherty TA, Broide DH. Pathways to limit group 2 innate lymphoid cell activation. J Allergy Clin Immunol. 2017;139(5):1465-1467.

145. Ogasawara N, Poposki JA, Klingler AI, et al. IL-10, TGF-beta, and glucocorticoid prevent the production of type 2 cytokines in human group 2 innate lymphoid cells. J Allergy Clin Immunol.2018;141(3):1147-1151 e1148.

146. Schleimer RP, Freeland HS, Peters SP, Brown KE, Derse CP. An assessment of the effects of glucocorticoids on degranulation, chemotaxis, binding to vascular endothelium and formation of leukotriene B4 by purified human neutrophils. J Pharmacol Exp Ther.1989;250(2):598-605.

147. Ray A, Kolls JK. Neutrophilic Inflammation in Asthma and Association with Disease Severity. Trends Immunol.2017;38(12):942-954.

148. Chong LY, Head K, Hopkins C, Philpott C, Burton MJ, Schilder AG. Different types of intranasal steroids for chronic rhinosinusitis. Cochrane Database Syst Rev. 2016;4:CD011993.

149. Kalish L, Snidvongs K, Sivasubramaniam R, Cope D, Harvey RJ. Topical steroids for nasal polyps. Cochrane Database Syst Rev.2012;12:CD006549.

150. Head K, Chong LY, Piromchai P, et al. Systemic and topical antibiotics for chronic rhinosinusitis. Cochrane Database Syst Rev. 2016;4:CD011994. 
151. Zhou B, He G, Liang J, et al. Mometasone furoate nasal spray in the treatment of nasal polyposis in Chinese patients: a double-blind, randomized, placebo-controlled trial. Int Forum Allergy Rhinol.2016;6(1):88-94.

152. Hissaria P, Smith W, Wormald PJ, et al. Short course of systemic corticosteroids in sinonasal polyposis: a double-blind, randomized, placebo-controlled trial with evaluation of outcome measures. J Allergy Clin Immunol. 2006;118(1):128-133.

153. Britt RD, Jr., Thompson MA, Sasse S, Pabelick CM, Gerber AN, Prakash YS. Th1 cytokines TNFalpha and IFN-gamma promote corticosteroid resistance in developing human airway smooth muscle. Am $J$ Physiol Lung Cell Mol Physiol. 2019;316(1):L71-L81.

154. Nabe T. Steroid-Resistant Asthma and Neutrophils. Biol Pharm Bull. 2020;43(1):31-35.

155. Harvey RJ, Snidvongs K, Kalish LH, Oakley GM, Sacks R. Corticosteroid nasal irrigations are more effective than simple sprays in a randomized double-blinded placebo-controlled trial for chronic rhinosinusitis after sinus surgery. Int Forum Allergy Rhinol.2018;8(4):461-470.

156. Kern RC, Stolovitzky JP, Silvers SL, et al. A phase 3 trial of mometasone furoate sinus implants for chronic sinusitis with recurrent nasal polyps. Int Forum Allergy Rhinol. 2018;8(4):471-481.

157. Djupesland PG, Skretting A, Winderen M, Holand T. Breath actuated device improves delivery to target sites beyond the nasal valve.Laryngoscope. 2006;116(3):466-472.

158. Fokkens W, Reitsma S. New delivery forms of nasal corticosteroids.J Allergy Clin Immunol. 2019;143(1):87-88.

159. Tait S, Kallogjeri D, Suko J, Kukuljan S, Schneider J, Piccirillo JF. Effect of Budesonide Added to Large-Volume, Low-pressure Saline Sinus Irrigation for Chronic Rhinosinusitis: A Randomized Clinical Trial. JAMA Otolaryngol Head Neck Surg. 2018;144(7):605-612.

160. Leopold DA, Elkayam D, Messina JC, Kosik-Gonzalez C, Djupesland PG, Mahmoud RA. NAVIGATE II: Randomized, double-blind trial of the exhalation delivery system with fluticasone for nasal polyposis. $J$ Allergy Clin Immunol. 2019;143(1):126-134 e125.

161. Sekiyama A, Gon Y, Terakado M, et al. Glucocorticoids enhance airway epithelial barrier integrity. Int Immunopharmacol.2012;12(2):350-357.

162. Steelant B, Farre R, Wawrzyniak P, et al. Impaired barrier function in patients with house dust miteinduced allergic rhinitis is accompanied by decreased occludin and zonula occludens- 1 expression. $J$ Allergy Clin Immunol. 2016;137(4):1043-1053 e1045.

163. Ordovas-Montanes J, Dwyer DF, Nyquist SK, et al. Allergic inflammatory memory in human respiratory epithelial progenitor cells. Nature. 2018;560(7720):649-654.

164. Corren J. New Targeted Therapies for Uncontrolled Asthma. J Allergy Clin Immunol Pract. 2019;7(5):1394-1403.

165. Ghogomu N, Kern R. Chronic rhinosinusitis: the rationale for current treatments. Expert Rev Clin Immunol. 2017;13(3):259-270.

166. Chin D, Harvey RJ. Nasal polyposis: an inflammatory condition requiring effective anti-inflammatory treatment. Curr Opin Otolaryngol Head Neck Surg. 2013;21(1):23-30.

167. Chandra RK, Kern RC, Cutler JL, Welch KC, Russell PT. REMODEL larger cohort with long-term outcomes and meta-analysis of standalone balloon dilation studies. Laryngoscope. 2016;126(1):44-50.

168. Leung RM, Kern RC, Conley DB, Tan BK, Chandra RK. Osteomeatal complex obstruction is not associated with adjacent sinus disease in chronic rhinosinusitis with polyps. Am J Rhinol Allergy.2011;25(6):401403. 
169. Snidvongs K, Kalish L, Sacks R, Sivasubramaniam R, Cope D, Harvey RJ. Sinus surgery and delivery method influence the effectiveness of topical corticosteroids for chronic rhinosinusitis: systematic review and meta-analysis. Am J Rhinol Allergy. 2013;27(3):221-233.

170. DeConde AS, Smith TL. Outcomes After Frontal Sinus Surgery: An Evidence-Based Review. Otolaryngol Clin North Am.2016;49(4):1019-1033.

171. Snidvongs K, Pratt E, Chin D, Sacks R, Earls P, Harvey RJ. Corticosteroid nasal irrigations after endoscopic sinus surgery in the management of chronic rhinosinusitis. Int Forum Allergy Rhinol.2012;2(5):415-421.

172. Bassiouni A, Ou J, Rajiv S, Cantero D, Vreugde S, Wormald PJ. Subepithelial inflammatory load and basement membrane thickening in refractory chronic rhinosinusitis with nasal polyposis: a histopathological study. Int Forum Allergy Rhinol.2016;6(3):248-255.

173. Jankowski R, Bodino C. Evolution of symptoms associated to nasal polyposis following oral steroid treatment and nasalization of the ethmoid-radical ethmoidectomy is functional surgery for NPS.Rhinology. 2003;41(4):211-219.

174. Barham HP, Ramakrishnan VR, Knisely A, et al. Frontal sinus surgery and sinus distribution of nasal irrigation. Int Forum Allergy Rhinol. 2016;6(3):238-242.

175. Alsharif S, Jonstam K, van Zele T, Gevaert P, Holtappels G, Bachert C. Endoscopic Sinus Surgery for Type-2 CRS wNP: An Endotype-Based Retrospective Study. Laryngoscope. 2019;129(6):1286-1292.

176. Morrissey DK, Bassiouni A, Psaltis AJ, Naidoo Y, Wormald PJ. Outcomes of modified endoscopic Lothrop in aspirin-exacerbated respiratory disease with nasal polyposis. Int Forum Allergy Rhinol. 2016;6(8):820825 .

177. Van Zele T, Holtappels G, Gevaert P, Bachert C. Differences in initial immunoprofiles between recurrent and nonrecurrent chronic rhinosinusitis with nasal polyps. Am J Rhinol Allergy.2014;28(3):192-198.

178. Lou H, Fang J, Li P, et al. Frequency, suppressive capacity, recruitment and induction mechanisms of regulatory $\mathrm{T}$ cells in sinonasal squamous cell carcinoma and nasal inverted papilloma. PLoS One.2015;10(5):e0126463.

179. Tokunaga T, Sakashita M, Haruna T, et al. Novel scoring system and algorithm for classifying chronic rhinosinusitis: the JESREC Study.Allergy. 2015;70(8):995-1003.

180. Khairuddin NK, Salina H, Gendeh BS, Wan Hamizan AK, Lund VJ. Quality of life and recurrence of disease in patients with eosinophilic and non-eosinophilic 1 chronic rhinosinusitis with nasal polyposis. Med J Malaysia. 2018;73(1):1-6.

181. Rosati D, Rosato C, Pagliuca G, et al. Predictive markers of long-term recurrence in chronic rhinosinusitis with nasal polyps. Am J Otolaryngol. 2020;41(1):102286.

182. Pan L, Liao B, Guo CL, et al. Inflammatory features and predictors for postsurgical outcomes in patients with nasal polyps stratified by local and systemic eosinophilia. Int Forum Allergy Rhinol. 2020.

183. Ryu G, Kim DK, Dhong HJ, et al. Immunological Characteristics in Refractory Chronic Rhinosinusitis with Nasal Polyps Undergoing Revision Surgeries. Allergy Asthma Immunol Res. 2019;11(5):664-676.

184. Bachert C, Mannent L, Naclerio RM, et al. Effect of Subcutaneous Dupilumab on Nasal Polyp Burden in Patients With Chronic Sinusitis and Nasal Polyposis: A Randomized Clinical Trial. JAMA.2016;315(5):469479.

185. Chang TW, Davis FM, Sun NC, Sun CR, MacGlashan DW, Jr., Hamilton RG. Monoclonal antibodies specific for human IgE-producing B cells: a potential therapeutic for IgE-mediated allergic diseases.Biotechnology (N Y). 1990;8(2):122-126. 
186. Bachert C, Han JK, Wagenmann M, et al. EUFOREA expert board meeting on uncontrolled severe chronic rhinosinusitis with nasal polyps (CRSwNP) and biologics: Definitions and management. $J$ Allergy Clin Immunol. 2021;147(1):29-36.

187. Hopkins C, Slack R, Lund V, Brown P, Copley L, Browne J. Long-term outcomes from the English national comparative audit of surgery for nasal polyposis and chronic rhinosinusitis. Laryngoscope.2009;119(12):2459-2465.

188. Smith TL, Schlosser RJ, Mace JC, et al. Long-term outcomes of endoscopic sinus surgery in the management of adult chronic rhinosinusitis. Int Forum Allergy Rhinol. 2019;9(8):831-841.

189. Smith KA, Orlandi RR, Oakley G, Meeks H, Curtin K, Alt JA. Long-term revision rates for endoscopic sinus surgery. Int Forum Allergy Rhinol. 2019;9(4):402-408.

Table 1

\begin{tabular}{|c|c|c|c|c|c|c|}
\hline Biologic & $\begin{array}{l}\text { Dupilumab } \\
\text { (anti } \\
\text { IL-4R[?]) }\end{array}$ & $\begin{array}{l}\text { Dupilumab } \\
\text { (anti } \\
\text { IL-4R[?]) }\end{array}$ & $\begin{array}{l}\text { Omalizumab } \\
(\text { anti IgE })^{2}\end{array}$ & 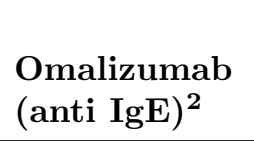 & $\begin{array}{l}\text { Mepolizumab } \\
\text { (anti } \\
\text { IL-5) }\end{array}$ & $\begin{array}{l}\text { Benralizumab } \\
\text { (anti } \\
\text { IL-5R[?])* }\end{array}$ \\
\hline $\begin{array}{l}\text { Study } \\
\text { Name } \\
\text { (Total } \\
\text { numbers) } \\
\text { Treatment } \\
\text { Duration }\end{array}$ & $\begin{array}{l}\text { SINUS-24 } \\
(\mathrm{N}=276) \\
24 \text { weeks }\end{array}$ & $\begin{array}{l}\text { SINUS-52 } \\
(\mathrm{N}=448) \\
52 \text { weeks }\end{array}$ & $\begin{array}{l}\text { POLYP } 1 \\
(\mathrm{~N}=138) \\
24 \text { weeks }\end{array}$ & $\begin{array}{l}\text { POLYP } 2 \\
(\mathrm{~N}=127) \\
24 \text { weeks }\end{array}$ & $\begin{array}{l}\text { SYNAPSE } \\
(\mathrm{N}=407) \\
52 \text { weeks }\end{array}$ & $\begin{array}{l}\text { OSTRO } \\
(\mathrm{N}=413) \\
56 \text { weeks }\end{array}$ \\
\hline \multirow[t]{4}{*}{$\begin{array}{l}\text { Co-Primary } \\
\text { Outcomes }\end{array}$} & $\begin{array}{l}\text { LS mean } \\
\text { difference in } \\
\text { NPS vs } \\
\text { placebo (scale } \\
0-8) 95 \% \text { CI } \\
\text { (P value) }\end{array}$ & $\begin{array}{l}\text { LS mean } \\
\text { difference in } \\
\text { NPS vs } \\
\text { placebo (scale } \\
0-8) 95 \% \text { CI } \\
\text { ( } \mathrm{P} \text { value) }\end{array}$ & $\begin{array}{l}\text { Treatment } \\
\text { arm difference } \\
\text { in NPS vs } \\
\text { placebo (scale } \\
0-8) 95 \% \mathrm{Cl}(\mathrm{P} \\
\text { value) }\end{array}$ & $\begin{array}{l}\text { Treatment } \\
\text { arm difference } \\
\text { in NPS vs } \\
\text { placebo (scale } \\
0-8) 95 \% \mathrm{Cl}(\mathrm{P} \\
\text { value) }\end{array}$ & $\begin{array}{l}\text { Difference in } \\
\text { median change } \\
\text { from baseline } \\
\text { for NPS (scale } \\
0-8) 95 \% \mathrm{Cl}(\mathrm{P} \\
\text { value) }\end{array}$ & NPS \\
\hline & $\begin{array}{l}-2.06-2.43 \\
-1.69 \\
(\mathrm{P}<0.0001)\end{array}$ & $\begin{array}{l}-1.80-2.10 \\
-1.51 \\
(\mathrm{P}<0.0001)\end{array}$ & $\begin{array}{l}-1.14-1.59 \\
-0.69 \\
(\mathrm{P}<0.0001)\end{array}$ & $\begin{array}{l}-0.59-1.05 \\
-0.12 \\
(\mathrm{P}=0.0140)\end{array}$ & $\begin{array}{l}-0.73-1.11 \\
-0.34 \\
(\mathrm{P}<0.001)\end{array}$ & $\begin{array}{l}\text { Met primary } \\
\text { endpoint }\end{array}$ \\
\hline & $\begin{array}{l}\text { LS mean } \\
\text { difference in } \\
\text { NCS vs } \\
\text { placebo (scale } \\
0-3) 95 \% \mathrm{Cl}(\mathrm{P} \\
\text { value) }\end{array}$ & $\begin{array}{l}\text { LS mean } \\
\text { difference in } \\
\text { NCS vs } \\
\text { placebo (scale } \\
0-3) 95 \% \mathrm{Cl}(\mathrm{P} \\
\text { value) }\end{array}$ & $\begin{array}{l}\text { Treatment } \\
\text { arm difference } \\
\text { in NCS vs } \\
\text { placebo (scale } \\
0-3) 95 \% \mathrm{Cl}(\mathrm{P} \\
\text { value) }\end{array}$ & $\begin{array}{l}\text { Treatment } \\
\text { arm difference } \\
\text { in NCS vs } \\
\text { placebo (scale } \\
0-3) 95 \% \mathrm{Cl}(\mathrm{P} \\
\text { value) }\end{array}$ & $\begin{array}{l}\text { Difference in } \\
\text { median change } \\
\text { from baseline } \\
\text { in nasal } \\
\text { obstruction } \\
\text { VAS score } 95 \% \\
\mathrm{Cl}(\mathrm{P} \text { value) }\end{array}$ & $\begin{array}{l}\text { Nasal blockage } \\
\text { score }\end{array}$ \\
\hline & $\begin{array}{l}-0.89-1.07 \\
-0.71 \\
(P<0.0001)\end{array}$ & $\begin{array}{l}-0.87-1.03 \\
-0.71 \\
(\mathrm{P}<0.0001)\end{array}$ & $\begin{array}{l}-0.55-0.84 \\
-0.25 \\
(\mathrm{P}=0.0004)\end{array}$ & $\begin{array}{l}-0.50-0.80 \\
-0.19 \\
(\mathrm{P}=0.0017)\end{array}$ & $\begin{array}{l}-3.14-4.09 \\
-2.18 \\
(\mathrm{P}<0.001)\end{array}$ & $\begin{array}{l}\text { Met primary } \\
\text { endpoint }\end{array}$ \\
\hline $\begin{array}{l}\text { Secondary } \\
\text { Outcomes }\end{array}$ & $\begin{array}{l}\text { Significant } \\
\text { improvement } \\
\text { with } \\
\text { dupilumab vs } \\
\text { placebo (week } \\
24 \text { ) }\end{array}$ & $\begin{array}{l}\text { Significant } \\
\text { improvement } \\
\text { with } \\
\text { dupilumab vs } \\
\text { placebo (week } \\
24 \text { ) }\end{array}$ & $\begin{array}{l}\text { Significant } \\
\text { improvement } \\
\text { with } \\
\text { omalizumab vs } \\
\text { placebo (week } \\
24 \text { ) }\end{array}$ & $\begin{array}{l}\text { Significant } \\
\text { improvement } \\
\text { with } \\
\text { omalizumab vs } \\
\text { placebo (week } \\
24 \text { ) }\end{array}$ & $\begin{array}{l}\text { Significant } \\
\text { improvement } \\
\text { with } \\
\text { mepolizumab } \\
\text { vs placebo } \\
\text { (week } 52 \text { ) }\end{array}$ & $\begin{array}{l}\text { NOT } \\
\text { PUBLISHED }\end{array}$ \\
\hline
\end{tabular}




\begin{tabular}{|c|c|c|c|c|c|c|}
\hline Biologic & $\begin{array}{l}\text { Dupilumab } \\
\text { (anti } \\
\text { IL-4R[?]) }{ }^{1}\end{array}$ & $\begin{array}{l}\text { Dupilumab } \\
\text { (anti } \\
\text { IL-4R[?]) }\end{array}$ & $\begin{array}{l}\text { Omalizumab } \\
\text { (anti IgE) }^{2}\end{array}$ & $\begin{array}{l}\text { Omalizumab } \\
\text { (anti IgE) }^{2}\end{array}$ & $\begin{array}{l}\text { Mepolizumab } \\
\text { (anti } \\
\text { IL-5) }\end{array}$ & $\begin{array}{l}\text { Benralizumab } \\
\text { (anti } \\
\text { IL-5R[?])* }\end{array}$ \\
\hline & $\begin{array}{l}\text { Quality of } \\
\text { life } \\
\text { (SNOT-22) } \\
\text { Total } \\
\text { symptom } \\
\text { score Sense } \\
\text { of smell } \\
\text { (UPSIT) } \\
\text { and loss of } \\
\text { smell score } \\
\text { Radio- } \\
\text { graphic } \\
\text { assessment } \\
\text { (Lund- } \\
\text { Mackay } \\
\text { score) } \\
\text { Increased } \\
\text { time to oral } \\
\text { corticos- } \\
\text { teroids or } \\
\text { surgery }\end{array}$ & $\begin{array}{l}\text { Quality of } \\
\text { life } \\
\text { (SNOT-22) } \\
\text { Total } \\
\text { symptom } \\
\text { score Sense } \\
\text { of smell } \\
\text { (UPSIT) } \\
\text { and loss of } \\
\text { smell score } \\
\text { Radio- } \\
\text { graphic } \\
\text { assessment } \\
\text { (Lund- } \\
\text { Mackay } \\
\text { score) } \\
\text { Increased } \\
\text { time to oral } \\
\text { corticos- } \\
\text { teroids or } \\
\text { surgery }\end{array}$ & $\begin{array}{l}\text { UPSIT and } \\
\text { loss of smell } \\
\text { score } \\
\text { SNOT-22 } \\
\text { score UPSIT } \\
\text { score TNSS }\end{array}$ & $\begin{array}{l}\text { UPSIT and } \\
\text { loss of smell } \\
\text { score } \\
\text { SNOT-22 } \\
\text { score UPSIT } \\
\text { score TNSS }\end{array}$ & $\begin{array}{l}\text { SNOT-22 } \\
\text { VAS score } \\
\text { Loss of smell } \\
\text { Reduced } \\
\text { need for } \\
\text { surgery } \\
\text { Reduced } \\
\text { need for } \\
\text { systemic } \\
\text { corticos- } \\
\text { teroid } \\
\text { use }\end{array}$ & \\
\hline $\begin{array}{l}\text { Adverse } \\
\text { reactions } \\
\text { with active } \\
\text { drug }\end{array}$ & $\begin{array}{l}\text { Injection site } \\
\text { reaction, } \\
\text { transient } \\
\text { eosinophilia, } \\
\text { conjunctivitis } \\
\text { ( } 7 \text { cases), } \\
\text { EGPA (1 } \\
\text { case), } \\
\text { eosinophilia } \\
\text { with arthralgia } \\
\text { (1 case) }\end{array}$ & $\begin{array}{l}\text { Injection site } \\
\text { reaction, } \\
\text { transient } \\
\text { eosinophilia, } \\
\text { conjunctivitis } \\
\text { ( } 7 \text { cases), } \\
\text { EGPA (1 } \\
\text { case), } \\
\text { eosinophilia } \\
\text { with arthralgia } \\
\text { (1 case) }\end{array}$ & $\begin{array}{l}\text { Headache, } \\
\text { injection site } \\
\text { reaction, } \\
\text { dizziness, } \\
\text { upper } \\
\text { abdominal } \\
\text { pain }\end{array}$ & $\begin{array}{l}\text { Headache, } \\
\text { injection site } \\
\text { reaction, } \\
\text { dizziness, } \\
\text { upper } \\
\text { abdominal } \\
\text { pain }\end{array}$ & Nasopharyngitis & \\
\hline
\end{tabular}

1. Bachert C, et al. Lancet 2019;394:1638-1650

2. Gevaert P, et al. J Allergy Clin Immunol 2020;146:595-605

3. Eur Respir J 2020;56:Suppl. 64, 4616

*Press release September 2020

LS: least squares; NPS: nasal polyp score; NCS: nasal congestion score; SNOT-22: Sino-nasal Outcome Test; UPSIT: University of Pennsylvania Smell Identification Test; VAS: visual analog scale; TNSS: Total nasal symptom score

EGPA: eosinophilic granulomatosis with polyangiitis

Figure Legends

Figure 1. Gene expression patterns in sinonasal tissue from patients undergoing surgery in Chicago at Northwestern. Data are from samples from patients with no sinonasal disease (Control, $n=11)$, CRSsNP (9 
TunsNP, 5 T1sNP, 8 T2sNP and 5 T3sNP) and CRSwNP ( 8 ET and 9 NP). The heatmap shows genes with more than 3-fold elevated levels in T1sNP, T2sNP or T3sNP compared to controls. Inspection of the gene expression patterns shows that CRSwNP samples from ethmoid and from nasal polyps are closely aligned with the T2 patterns seen in ethmoid tissue from a subset of patients with CRSsNP. The figure was adapted from published studies by Klingler al ${ }^{55}$. Tun - untypeable, T1 - Type 1 endotype, T2 - Type 2 endotype and T3 - Type 3/17 endotype (see text). ET - ethmoid tissue, NP - nasal polyp tissue.

Figure 2 . Overview of the primary cytokines driving T1, T2 and T3 endotypes, the source cells producing the primary cytokines and the effector cells that are recruited to the tissue and activated. Classical endotype refers to earlier endotyping based on the presence or absence of eosinophils. The natural pathogenic targets of each immunological endotype are listed at the bottom of the figure.

Figure 3 . Summary of the major biomarker genes whose expression is elevated in the T1, T2 and T3 endotypes of CRS (whether CRSsNP or CRSwNP). Also shown are the "mixed" endotypes, as indicated by T1,3, T1,2 and T2,3. Not shown are $\mathrm{T}$ untypeable (Tun), which do not express the biomarker genes or $\mathrm{T} 1,2,3$, a rare group of patients that have elevated levels of all three sets of biomarker genes.

Figure 4. Overview of recent studies linking disease phenotypic signs and symptoms with molecular endotype, showing the changes in prevalence of each phenotype in the indicated endotypes. It is anticipated that future studies will increasingly link phenotypic signs and symptoms with underlying endotype to better define pathogenic mechanisms and indicate appropriate treatment regimens. 